DE ECONOMIST 158, NO. 1, 2010

\title{
BANKING AND DEBT CRISES IN EUROPE: THE DANGEROUS LIAISONS?
}

BY

\author{
BERTRAND CANDELON*, FRANZ C. PALM ${ }^{* *, * * *}$
}

\begin{abstract}
Summary
The potential mutation of the Sub-Prime banking crisis into a sovereign debt one in Euro area countries is investigated. After reviewing the criteria used to measure the debt vulnerability, the balance sheet approach is presented in order to illustrate the potential connections between these two types of crises. A graphical analysis yields evidence that at the end 2009 the probability of observing a Euro area country defaulting is less likely than six month before. Nevertheless, the serious threats, which concern Greece and Ireland, do not permit us to exclude the occurrence of a contagious, or self-fulfilling, sovereign debt or currency crises in Euro area in the future.
\end{abstract}

Key words: Banking crisis, Sovereign debt crisis, European Union

JEL Code(s): E32, F36

\section{INTRODUCTION}

Since the beginning of the year 2010, more and more voices proclaim that the Sub-Prime banking crisis has entered its last stage of infection. After hitting the U.S. real estate markets, the banking sector, and the stock exchange markets all over the world, it is affecting for a while the real sector (unemployment, in particular), before hopefully disappearing. As a virus, it might then be frozen for a while, before stemming back again. But as economic systems learned from this event, they will be stronger and hopefully immune from this new virus. Nevertheless, some concerns remain about the possible mutation and resurgence of the crisis in another type of turmoil. For example, in November 30, 2009 in the Korean Times, Kenneth Rogoff wrote that "Essentially, there is still a risk that the financial crisis is simply hibernating as it slowly morphs into a government debt crisis". It is also important to

* Corresponding author: Department of Economics, University Maastricht School of Business and Economics, PO BOX 616, MD 6200 Maastricht, The Netherlands, e-mail: b.candelon@maastrichtuniversity.nl

** Department of Quantitative Economics, University Maastricht School of Business and Economics, PO BOX 616, MD 6200 Maastricht, The Netherlands, e-mail: f.palm@maastrichtuniversity.nl

*** CESifo, Munich, Germany 
notice this potential fear is not simply limited to emerging economies, such as Dubai or Ukraine, or third world countries but also concerns industrialized countries as well. In particular, the threat of a sovereign debt crisis is present for Euro area members, such as Ireland, Greece, Spain and Portugal. This regional dispersion constitutes a specificity of the current crisis, ${ }^{1}$ as episodes in which a European country was in default are historically extremely rare (for example, Reinhart and Rogoff 2009 only list 13 of these periods in Spain since 1476, and 8 in France since 943!!). Moreover, the adoption of a single currency and the various agreements related to it, such as the Stability and Growth Pact (SGP), should have avoided the occurrence of such debt default episodes.

Recent literature has widely examined the potential linkages between a currency and a banking crisis, to assess the likelihood of a twin crisis. Typically, a sharp collapse on exchange rate markets endangers financial investments and may lead to liquidity problems, and even bankruptcy of financial institutions. Similarly, the consequences of fiscal imbalances for currency/ banking crises has been largely investigated. The seminal model of Flood and Garber (1984), provides a theoretical explanation for the occurrence of a currency crisis stemming from incoherent macroeconomic policies, and in particular an uncontrolled monetary expansion, which can be easily extended for monetized excessive public deficits (see inter alii, Corsetti and Mackowiak 2006). On the contrary, only few papers have scrutinized the potential mutation of banking crises into sovereign debt ones. Three types of linkages can be established. In a first instance, in reaction to a banking crisis, governments set up safety plans leading to an increase in public deficits. Financial institutions can also be supported by off-balance sheet operations such as government guarantees to commercial banks. The fiscal cost of the latter measure is difficult to evaluate as there is no direct liquidity support, but the risk associated with the potential exercise of the guarantee leads investors to ask a higher risk premium from the country or institution providing the insurance. Finally, the real consequences associated with the banking crisis (higher unemployment,...) affect government tax revenues, which will shrink, and government spending, which will rise, through social security (unemployment benefits,...) and through measures designed to stimulate global demand. This automatic stabilizer mechanism deepens the budget deficit and increases the debt, calling for even more procyclical discretionary fiscal policies. This mechanism is particularly important for members of the European Monetary Union that committed themselves to limiting their fiscal deficits and debt in the SGP. As a consequence, this restrictive fiscal policy could increase the probability of default for households, increasing the amount on non-performing loans, again putting tensions on the banks' balance sheet. 
Empirically, Reinhart and Rogoff $(2008 \mathrm{a}, \mathrm{b})$ even portrayed this lack of empirical studies relating banking and debt crises as 'a forgotten story', and proposed a historical analysis beginning in 1900 for a large set of developed and industrialized countries. They report for each year the proportion of banking and debt crisis episodes. It turns out that financial sector turbulences had consequences for sovereign default crisis, increasing the likelihood of the Sub-Prime crisis to mute into sovereign debt problems.

The main reason for the relative lack of empirical studies lies in the difficulty to diagnose the occurrence of a sovereign debt crisis. The strict definition stating that a country is facing a debt crisis, when it cannot pay for the interest or the principal of its foreign debt, is much too restrictive and would leave us with the impression that none of the European countries are facing a crisis at the moment. Similarly, providing a debt threshold beyond which a sovereign debt crisis is detected is also not operational in practice, as it would have to be country specific. For example, as Euro area countries have a stable currency and are likely to assist each other in case of difficulty in paying debt services, the threshold beyond which a Euro area country experiences a sovereign debt crisis would be higher than for a non-member country. For example, Italy and Greece were experiencing public debt exceeding $100 \%$ of the gross domestic product (gdp) without being in a formal crisis situation. For the detection of a sovereign debt crisis, one could also rely on agency ratings (Moodys or Standard and Poors), or on the spread between government bond interest rate of a country and that of a virtuous one (usually Germany or the U.S.) as this spread provides a direct indication of the refinancing costs for a government on a market. A country, with a higher risk of default, faces a higher refinancing cost of public deficits. In fact, these three measures are indicators of the debt vulnerability of the country.

The paper intends to shed some light on the potential linkages between banking and sovereign crises. It is intended to provide a better understanding of the potential mutation of the Sub-Prime turmoil into a sovereign debt crisis in the Euro area. Section 2 is devoted to the definition of a sovereign debt crisis. In Section 3, a balance sheet approach is used to explain the linkages between banking and debt crises. Section 4 provides an empirical analysis of the current situation for Euro area countries. Final Section 5 concludes.

\section{DEFINITIONS}

The relative scarcity of studies relating banking to debt crises is mainly due to the problems of providing operational definitions of these events, and in particular the timing and duration of debt crisis.

Intuitively, a country facing problems with the payment of the interest or the principal of its foreign debt, experiences a crisis on external sovereign debt. In other words, during a debt crisis, the country faces defaulting its 
debt services like an à part entière household. Nevertheless, although such a definition of a debt crisis has the advantage of simplicity, it is much too narrow to be used as an operational tool to detect a debt crisis in an early stage, which would allow for taking measures to avoid defaulting. Defining a debt crisis as a period of debt-services default for a specific country would lead to detecting only a few crises, with the most extreme ones corresponding to official defaults (Russia 1998 or Argentina, 2001). In practice, countries rarely officially announce that they are defaulting, since the consequences for their credibility would be disastrous. According to Moody's Investors Service (2003), only seven rated sovereign bond issuers would have defaulted on their foreign currency-denominated bonds since 1985, and all those defaults occurred between 1998 and 2002. For example, the famous Brazilian "crisis" in 1994-95 would not have been labeled a debt crisis, despite the substantial IMF assistance, as it did not result in sovereign default.

A first direct indicator of a debt crisis would be an important increase in the ratio of public debt-gdp. Beyond a certain threshold, one would conclude that a country is facing a problem in financing the debt service. Even if this quantity based measure is relatively simple, nevertheless it neglects the cost of the debt: in some cases, it is better to have a high debt at a low cost than a low debt at a high rate. Moreover, the threshold beyond which a crisis is detected depends on the country: The recent literature on debt (See Reinhart et al. 2003; Manasse et al. 2003) shows that developing countries historically have run into problems at much lower debt-to-output ratios than advanced countries. One of the reasons is that investors might have more confidence in a developed country with high debt, than a developing one with low debt. For such a reason, a debt crisis is hardly detected in Japan, where the debtgdp ratio is reaching 200\% whereas Uruguay experienced a debt crisis in 2002 when this ratio was close to $100 \%$. Finally, debt statistics are extracted from national accounts. They are therefore potentially revisable until 2 years after their first publication, and consequently early releases have to be interpreted with caution.

Market-based measures appear then more adequate as countries can find sufficient liquidity on sovereign bond markets, under the condition that capital is mobile. These markets developed in the 1990's fueled up with public debt and made it relatively easy for a country facing debt-servicing difficulties to issue bonds to cover its liquidity demand. Nevertheless, a country with a high risk of default should expect to reward investors with a consequent risk premium, leading to higher refinancing costs. Again, the similarity with a household is obvious: if you ask for a loan and show the bank that you have enough financial capacities to pay it back, the cost of the loan will be low. The refinancing rate is a good proxy of the investors feeling for the sustainability of a country's sovereign debt, especially for countries having the same 
currency. ${ }^{2}$ Pescatori and Sy (2007) thus use the bond spread between risky and less risky countries as an indicator of tension on the sovereign bond market. Once this spread crosses a certain threshold, ${ }^{3}$ a debt crisis is diagnosed. Using this criterion, the number of crises jumps to 168 for the period 19751993 !

Another possibility consists in relying on rating agencies (such as Standard and Poors, Fitch or Moodys) and adopting rating-based measures of the sovereign debt crisis. Rating agencies evaluate the risk associated with sovereign debt, ranking them in several groups. The risk models are specific, most of the time based on expert's judgments and thus may vary from one agency to another. ${ }^{4}$ Moreover, as the ranking is discrete, the consequences of a downgrading are strong. Just to give an example, the announcement of a future downgrading of the Greek sovereign bond on February 24, 2010 caused a decrease of $2 \%$ in most of European stock markets. Rating agencies are thus up or downgrading with prudence, ${ }^{5}$ especially when it concerns a developed country, to avoid provoking the precipitation of the crisis. The prudence leads to the introduction of important delays in the crisis dating, and to overestimate inertia for some countries. To illustrate this point, we report in Fig. 2 the path of the debt to GDP ratio, the sovereign ratings, and the government bond spread for 11 European countries, ${ }^{6}$ which belong to the Euro area and the United Kingdom for the period 2000-2009. Debt series were extracted from the database $A M E C O$ from the European Commission, while the sovereign ratings were provided by Standard and Poors $(S \& P){ }^{7}$ The government bond yields (usually 10 years) were taken the IFS database of the IMF, and the spreads were calculated considering Germany as the reference country. All series are at the yearly frequency.

It turns out that sovereign ratings are constant over the period for half of the countries (Austria, Belgium, France, Germany, the Netherlands and the U.K.). ${ }^{8}$ Only Portugal has been downgraded to a higher risk group. For this reason, this measure will not be used in the rest of the paper. Debt-gdp ratios show a lower inertia, and exhibit a negative trend before the Sub-Prime crisis. Since 2007, they strongly increase, reaching in 2009 a level higher than in

2 In the cases, of countries with different currencies, the refinancing rate also integrates the currency risk.

3 Sy (2004) estimates a value around 1,000 basis points for a set of emerging countries.

4 See Cantor and Packer (1995).

5 The question of the political independence of these rating agencies can also been raised, as they are mainly financed by developed countries.

6 Austria, Belgium, France, Germany, Greece, Ireland, Italy, Luxembourg, the Netherlands, Portugal, Spain and the U.K.

7 Data are taken from Slavila (2008). For Greece, instead of the $S \& P$ sovereign debt rating, we reported Moody's rating.

8 Five out of these six countries have a constant $A A A$ rate and thus belong to the lowest risk group. 
2000. Government bond spreads are as volatile as the debt-gdp ratio. Interestingly, it turns out that the turning point for spreads took place around 2006, i.e. a year before the increase in the debt-gdp ratio. Such an observation is not surprising at all, as these risk premiums are determined by the markets, which integrate quickly and even anticipate news.

\section{THE LINKAGES BETWEEN BANKING AND DEBT CRISES}

\subsection{The Balance Sheet Approach (BSA)}

Theoretical models of financial crisis combine dynamic relationships (as uncovered interest rate parity, money demand) representing a flows approach, and accounting quantities (such as debt, foreign reserves,...) indicating stock variables, and reported in balance sheets of the government and the central bank. As an example, the Flood and Garber (1984) model for currency crisis includes three well-known log-linearized equations (money demand, uncovered interest rate parity, purchasing power parity)and an accounting relation from the from balance sheet of the central bank consolidated with that of the government. The determinants of real money demand are real domestic income, assumed to be exogenous, and nominal domestic interest rates. Purchasing power parity links the ratio of the domestic and the foreign price level to the nominal exchange rate. Uncovered interest rate parity relates the domestic to foreign nominal interest rate differential to the expected nominal exchange rate change, where expectations are assumed to be model-based (perfect foresight or rational). The nominal money supply is the only policy variable. From the central bank's balance sheet, it results that the monetary basis equals the book value of international reserves plus domestic credit. The central bank monetizes the fiscal branch's credit demand. If the consolidated government is printing money to finance government expenditures in a fixed exchange rate regime or in a monetary union (like the Euro area), the central bank can use up its foreign currency reserves to soak up any money the public does not want to hold at the fixed exchange rate. But such a policy would not be sustainable as the central bank will run out of foreign reserves, at which point it is not longer in a position to both finance the government deficits and to keep the money stock and the exchange rate fixed. Of course, the central bank could borrow foreign reserves for a while but at the cost of a higher risk premium, ${ }^{9}$ but this policy would not be sustainable. Fiscal austerity is the only remedy in such a situation, as long as the abandonment of the fixed exchange rate (in the case of European Monetary Union, it would consist in abandoning the Euro) is not considered. If it not the case, a crisis will arise from mismatches within the asset-liability part of the central bank

9 This policy is denominated as sterilization. 

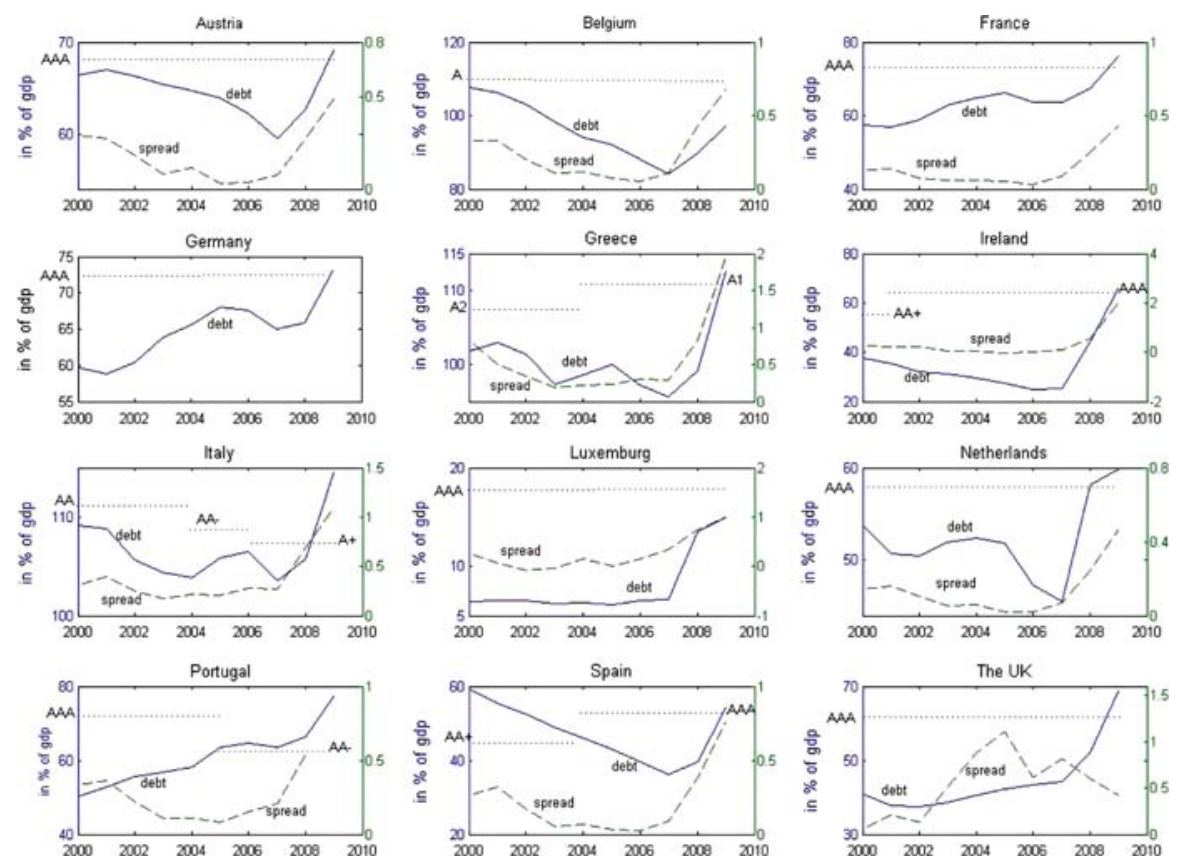

Figure 1 - Debt-gdp ratio, Government bond spread and sovereign debt ratings

balance sheet: the currency crisis situation corresponding to the case where the foreign reserves stock is exhausted in the asset part. In the Euro area, the room for policy discretion is further reduced by the European treaty, prohibiting the European Central Bank (ECB) to lend to member state governments (Fig. 1).

The Flood and Garber (1984) model considers exclusively the central bank balance sheet and thus it can only investigate the mechanism leading to currency crisis. In order to apprehend the potential mutation of a particular crisis into another type, BSA identifies next to the central bank three important balance sheets, associated respectively with the financial sector (banks), the non financial sector (firms and households), and the external sector. Figure 2 reports the potential linkages found by Rosenberg et al. (2005).

The concordance with Flood and Garber (1984) is done with the government sector balance, which includes the one of the central bank. Any shock to a specific balance sheet will have an effect on the other ones. As an example, the negative shock on the U.S. real estate price that has affected the non-financial balance sheet sector has been transmitted to the financial sector balance sheet (e.g. insolvency of households leads to losses for banks), and to the government one (e.g. reduction of tax income resulting from firm and 
household insolvency). Similarly a bank panic will hit the financial sector balance sheet first, but also the government's one via a decrease in the demand for government bonds. The (direct or indirect) impact of the shock will be more important the weaker the balance sheet is, i.e. the bigger the mismatch is. Rosenberg et al. (2005) find 3 types of mismatches: the currency mismatch (a higher amount of assets labeled in foreign currency creates a vulnerability to exchange rate shocks ${ }^{10}$ ), maturity mismatch (when long-run assets are excessive vis a vis of short run ones, the balance sheet is vulnerable to an increase in interest rates, as it increases the rolling over short-run liabilities) and market risks (a decrease in the price of an asset to which the balance sheet is over-exposed).

Using this BSA framework, it is thus possible to detect potential sources at the origin of the Sub-Prime banking crisis as the market risk (too high exposure of the financial sector balance sheet to real estate sector), and a maturity mismatch (too high proportion of long term loans, mortgage in particularly, in the liability part of the financial sector balance sheet), which lead to a bank panic. Similarly, BSA suggests one potential weakness fostering the transmission of the banking to a sovereign debt crisis consecutive to the contraction of the asset part of the financial sector balance sheet. It leads to a lower demand for public bonds, forcing government to enter massively the foreign bond markets, deteriorating thereby their external debt position. For a member of the Euro area countries, a deterioration of the debt position would lead to pay a default risk premium.

\subsection{Empirical Evidence}

Several papers evaluate the potential transmission of a banking crisis into a currency one (Glick and Hutchison 2000 for example ${ }^{11}$ ).

Interestingly, the linkages between banking and sovereign crises have been less investigated. However, several papers stress the ever growing real cost of banking crises. Bordo et al. (2001) found that the occurrence of a banking crisis increased since 1973 and their frequency is the same for emerging as

10 The adoption of a single currency in the Euro area should limit this type of risk.

11 They study the joint occurrence of banking and currency crises using the probit approach on a set of annual data of 90 developed and developing economies over 20 years from 1975 to 1997. They first estimate two probit equations, one for each type of crisis, and test empirically the causal link between crises by means of a contemporaneous and a lagged dummy variable. After controlling for the influence of a set of macro variables, they find a significant contemporaneous effect of currency crises in the banking distress equation, and significant contemporaneous and lagged effects of banking crises in the currency pressure equation in the emerging economies sub-sample. 


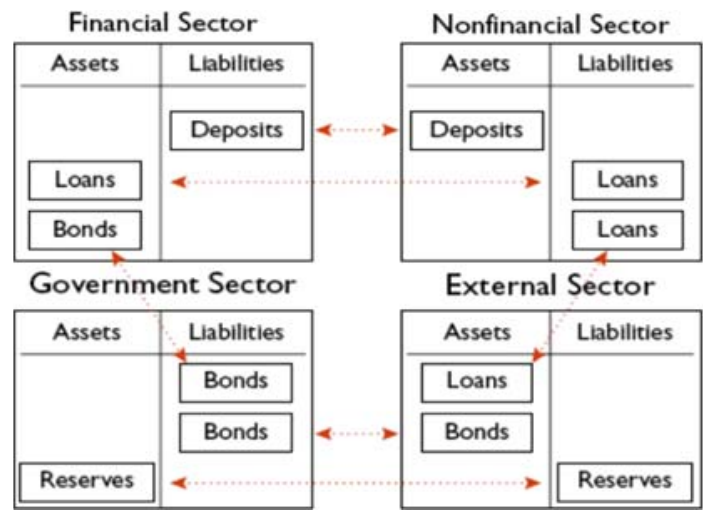

Figure 2 - Balance sheet approach (Source: Rosenberg et al. 2005, p. 5)

developed countries. ${ }^{12}$ They also showed that the real costs of banking crises have been increasing since the end of the 1970's and exceed those induced by a currency crisis. Indeed, it is likely that higher real costs will foster the mutation of the banking crisis into a sovereign debt one. Using an elaborated econometric model for a sample of 24 emerging countries, Hutchison and Noy (2006) confirm the outcomes of Bordo et al. (2001), finding that a banking crisis is on average followed by a $4.1 \%$ fall in real output growth and a recession lasting for two years. ${ }^{13}$ DellAriccia et al. (2008) go deeper and show that sectors more dependent on external finance perform relatively worse during banking crises and this too applies to countries with less access to foreign finance. ${ }^{14}$

Nevertheless, the empirical evidence on links between banking and sovereign debt crises is weaker. Hutchison and Noy (2006) for example do not find any significant direct effects on the public budget deficit, which represents an approximation of the growth rate of debt, after a banking crisis. On the contrary, Reinhart and Rogoff (2008a,b) consider the linkage in a historical analysis since 1900. They analyse a set of 66 countries and determine ex-post the proportion of banking and debt crises for every year. In Figure 3 , they report for each year the number of countries experiencing a banking and debt crisis

12 Reinhart and Rogoff (2008a) detected one banking crisis for EMU countries since 1945, but two in Spain and Germany. In the same period the United Kingdom experienced 4 of them.

13 In the cases of currency crises they find that it follows a recession of one year, resulting in a decrease in output of $1.3 \%$ ).

14 This matches the BSA links: in case of a banking crisis, financial sector demand less government bonds leading the government to ask for more liquidity on the external sector. 


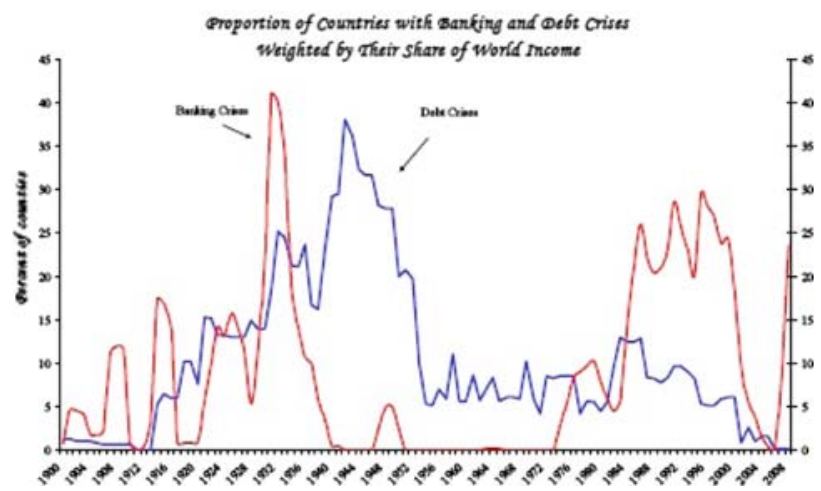

Figure 3 - Historical evolution of debt/banking crisis. Source: Reinhart and Rogoff (2008a) p. 10

and support the finding that sovereign debt episodes are following a banking crisis.

According to their estimates the stock of debt on average almost doubles (exactly multiplies by 1.86) three years after the banking crisis. Of course, the debt effect depends on the country considered and on several factors such as its initial amount of debt and its access to the foreign bond market. Interestingly, European countries are not always below the average of the debt-gdp ratio (e.g. Spain) stressing hence the debt vulnerability of these economies to a banking crisis.

A reverse effect (from debt to banking crisis) has also been established by Borensztein and Panizza (2009). Considering 149 countries for the 1975-2000 period, they diagnose 111 banking and 85 sovereign debt crises and they estimate that the risk to face a banking crisis after experiencing a sovereign debt crisis increases by $11 \%$ compared to a normal situation.

\section{THE 2008 SUB-PRIME CRISIS}

\subsection{Facts}

The Sub-Prime crisis takes its origin in the explosion of the real estate bubble in the U.S. in mid 2007. As the amount of assets linked to real estate, which were held by financial institutions was important and as these assets were often packaged in undiversified high risk, so-called structured products, banks and insurances presented weak balance sheets. Some financial institutions were experiencing liquidity problems and were already helped by governmental authorities (Northern Rock,...). In September 2008, Lehman Brothers went into bankruptcy provoking a 2-week tsunami on stock mar- 
TABLE 1 - FINANCIAL SECTOR FISCAL COSTS IN \% OF GDP

\begin{tabular}{lccllc}
\hline & $\begin{array}{l}\text { Capital } \\
\text { injections }\end{array}$ & $\begin{array}{l}\text { Purchase of } \\
\text { assets and } \\
\text { lending and } \\
\text { lending by } \\
\text { treasury }\end{array}$ & $\begin{array}{l}\text { Central bank } \\
\text { support } \\
\text { provided with } \\
\text { treasury } \\
\text { Backing }\end{array}$ & $\begin{array}{l}\text { Liquidity } \\
\text { provision by } \\
\text { central bank }\end{array}$ & Guarantees \\
\hline France & 1.2 & 1.3 & 0.0 & 0.0 & 16.4 \\
Germany & 3.7 & 0.4 & 0.0 & 0.0 & 17.6 \\
Italy & 1.3 & 0.0 & 0.0 & 2.5 & 0.0 \\
Netherlands & 3.4 & 2.8 & 0.0 & 0.0 & 33.7 \\
Spain & 0.0 & 4.6 & 0.0 & 0.0 & 18.3 \\
U.K. & 3.5 & 13.8 & 12.9 & 0.0 & 17.4 \\
\hline
\end{tabular}

Source: IMF 2009. The state of public finances: outlook and medium - term policies after the 2008 crisis.

kets. The inter-banking market stopped functioning, and governments were forced to intervene in order to stabilize the banking sector. These interventions have been carried out via on-balance sheet operations (capital injections, purchase of assets and liquidity provision by treasury and central bank support provided with treasury backing or by the central bank) and off-balance sheet guarantees. As shown in Table 1 the amount spent on these safety plans by European countries belonging to the $G 20$ were important, especially with respect to the guarantees, which do not appear in the government's balance sheet, but will be a risk factor in case they will be exercised. U.K. is the country, which provided the highest direct support to the financial sector (mainly via nationalization) in percent of gdp whereas the Netherlands offered the highest amounts of guarantees.

Governments used the sovereign bond markets to support these plans and to finance the recessionary real effects implied by the banking crisis. As a result, sovereign debt (measured by the debt-gdp ratio) jumped from 62 percent of World GDP in 2007 to 85\% in 2009 and according to the IMF projections it is expected to rise to $118 \%$ for G20 countries in 2014. Similarly, the average fiscal deficit in the G20 jumped from 1 to $7.9 \%$ in the same period of time.

The consequences of the Sub-Prime crisis of the debt vulnerability for European countries can be directly observed via the evolution of the debt-gdp ratio. Data are extracted from the AMECO database of the European Commission. These yearly data are available until 2010. Notice that the 2010 data is not observed, but forecasted in the legal framework established by the Stability and Growth Pact. 
TABLE 2 - DEBT-GDP RATIO

\begin{tabular}{|c|c|c|c|c|c|}
\hline \multirow[t]{2}{*}{ Period } & \multicolumn{3}{|c|}{ Growth rate in $\%$} & \multicolumn{2}{|c|}{ Levels in $\%$} \\
\hline & 07-08 & 08-09 & $09-10 *$ & 08 & 09 \\
\hline Austria (Aus) & 5.33 & 10.30 & 7.02 & 62.64 & 69.10 \\
\hline Belgium (Bel) & 6.66 & 8.14 & 4.16 & 89.85 & 97.16 \\
\hline France (Fra) & 5.63 & 12.90 & 8.42 & 67.39 & 76.09 \\
\hline Germany (Ger) & 1.41 & 10.91 & 5.00 & 65.89 & 73.08 \\
\hline Greece (Gre) & 3.79 & 13.50 & 10.98 & 99.19 & 112.57 \\
\hline Ireland (Ire) & 75.36 & 49.33 & 25.98 & 44.08 & 65.83 \\
\hline Italy (Ita) & 2.16 & 8.31 & 1.84 & 105.77 & 114.56 \\
\hline Luxembourg (Lux) & 105.12 & 10.87 & 9.24 & 13.54 & 15.01 \\
\hline Netherlands (Net) & 27.94 & 2.77 & 9.67 & 58.18 & 59.79 \\
\hline Portugal (Por) & 4.24 & 16.70 & 9.27 & 66.32 & 77.39 \\
\hline Spain (Spa) & 9.81 & 36.67 & 22.18 & 39.70 & 54.25 \\
\hline U.K. (UK) & 17.64 & 31.96 & 17.03 & 52.00 & 68.62 \\
\hline
\end{tabular}

Note: Data corresponds to the general government consolidated gross debt, reported in the framework of the excessive deficit procedure (based on ESA 1995) (UDGG). Observations for 2010 are European Commission forecasts and revisions are possible 2 years after the first publication.

Table 2 gathers the debt-gdp ratio as well as its yearly growth rate for the period 2007-2010.

In 2009, the stock of debt exceeded $100 \%$ for Italy and Greece, and is in all cases larger than the $60 \%$ threshold imposed by the SGP. Similarly, the debt-gdp ratio increased for almost all countries, except Luxembourg, the Netherlands and Spain. The debt growth rate is thus positive in all Euro area since 2008. The highest variation is observed for the period 2008-2009. Nevertheless, it seems that a peak has been reached in 2009 as debt growth rates are expected to decrease from 2010 onward. We also remark a negative relationship between the level and the debt growth rate, indicating that countries with an important stock of debt experienced a lower increase in their debtgdp ratio.

The expected consequence of the deterioration of the public debt is that investors are requiring higher risk premiums. The government bond spread should thus exhibit a similar pattern as the debt. Figure 4 represents its monthly path since January 2008. Again the spread is calculated as the deviation from the German 10 year government bond interest rate. ${ }^{15}$ 

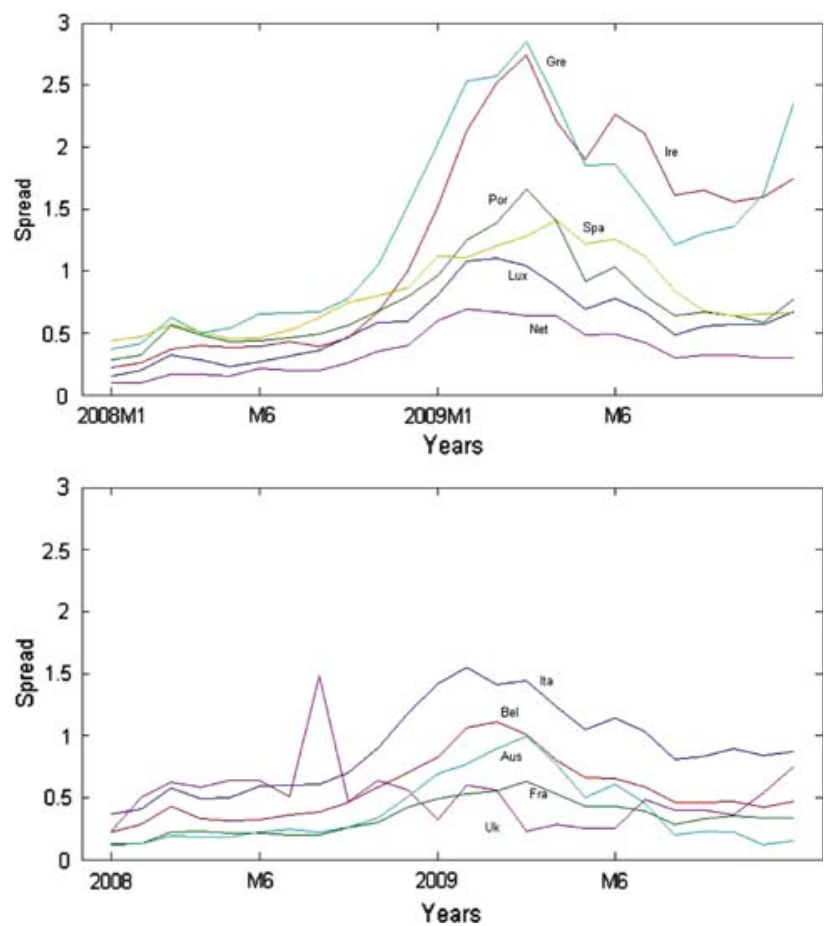

Figure 4 - Recent evolution of the government bond spread wrt Germany

Indeed, it appears that the spreads rose during the first semester of 2009 exceeding $1 \%$ differentials for all countries except for Austria, the Netherlands, France and the U.K. It almost jumped to 3\% for Greece and Ireland, which seem to be the countries that are the most likely to default according to financial market reactions. After mid-2009, the spreads fall again crossing back the $1 \%$ point differential indicating that tensions on sovereign debt, and thus the probability for a European country to default, is consequently lower than in the early 2009. Greece and Ireland constitute the exceptions, where risk premium is substantially going up again at the end of the year 2009. Government bond spreads also slightly rose for a group of countries inluding Portugal. So, markets are considering that the situation is getting tenser for these countries. It is noticeable that spreads are below the 1,000 bps threshold, a criterion proposed by Pescatori and Sy (2007) to detect a sovereign debt crisis in emerging countries. It indicates that the market still believes that the situation in Greece and Ireland is not alarming possibly because markets might be confident that they will be supported by other Euro area member states if necessary. Other countries like Spain and Portugal also experienced an increase in their government bond spread in 2009. Their spread has also 

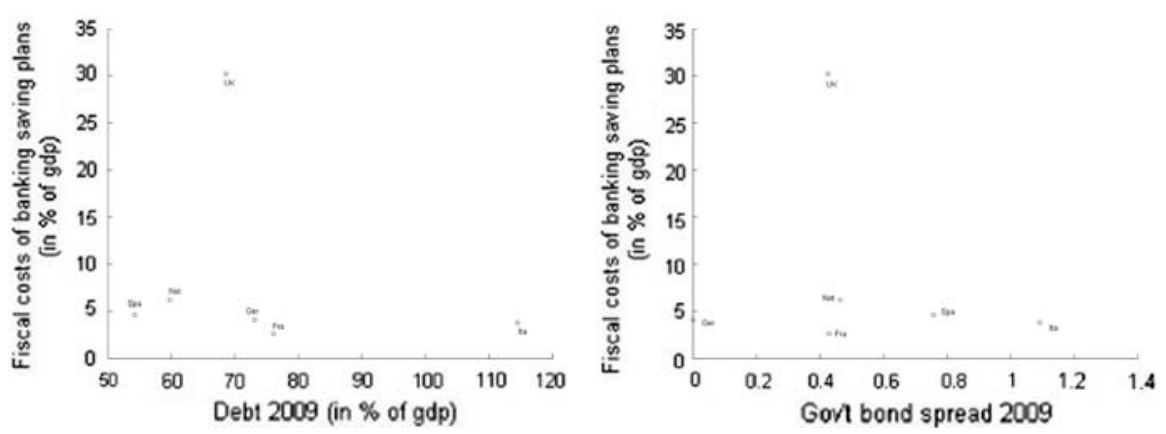

Figure 5 - Banking saving plan and sovereign debt crisis

decreased substantially during the second half 2009, which has subsequently increased again.

In order to investigate the link between the Sub-Prime crisis and the debt vulnerability (or the probability of sovereign debt crisis), we consider 3 indicators of the recent banking crisis: the total fiscal costs of the safety plans of the banking sector, the amount of guarantees provided by the state to the financial sector, and the decrease of the stock market index in 2008. ${ }^{16}$ Figures 5, 6 and 7 indicate the link that may prevail between these 3 measures and the indicators of sovereign debt crises (debt-gdp ratio and the government bond spread in 2009). It turns out that no clear link is observed when considering total fiscal costs of the safety plans of the banking sector or the guarantees provided by governments to the financial sector. The amount of support does not depend on the debt situation of the country. This result is not surprising when considering the guarantees, as they do not correspond to any direct costs as long as they are not exercised (except for the possibility that as a result of the support, the guarantor might have to pay a risk premium on its loans). With respect to the fiscal costs induced by the banking saving plan, they do not seem to have had much impact on the debt. ${ }^{17}$ This conclusion provides ex-post a motivation for the decision of European governments to support the banking sector to avoid its collapse.

On the contrary, a positive relationship can be detected between stock market losses and debt-gdp ratio (or government bond spread): countries facing the highest stock markets losses, are also the ones experiencing the highest debt-gdp ratio and the highest risk premium. It is possible to explain theo-

16 Fiscal cost data are extracted from the IMF's (2009) report on "The State of Public Finances: Outlook and Medium-Term Policies After the 2008 Crisis", stock exchange variations in 2008 are calculated using the datastream stock market local indices.

17 A similar conclusion can be reached when considering the growth rate of debt instead of its level. 

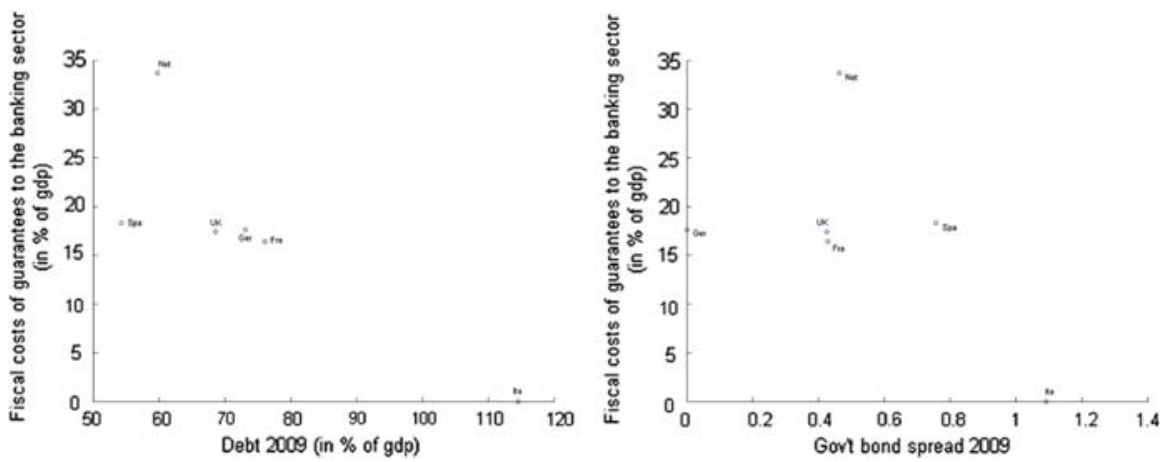

Figure 6 - Guarantee to banks and sovereign debt crisis
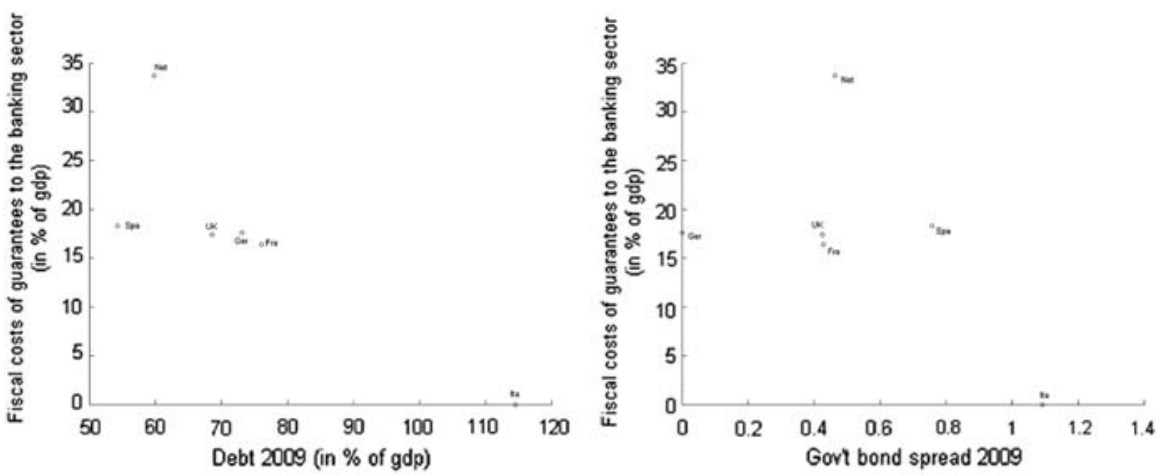

Figure 7 - Stock market growth and sovereign debt crisis

retically this linkage ${ }^{18}$ with a wealth effect (a decrease in stock market index leads to a negative wealth shock, having a negative impact on demand, implying a decrease in fiscal income and thus a degradation of the debt stock relative to the gdp) amplified by a decrease in output.

\subsection{Remaining Threats}

This graphical empirical analysis leaves us with the feeling that the increase in debt vulnerability observed in European countries is more driven by stock market losses than government interventions aimed at rescuing the banking sector. This constitutes a positive indication for the coming months as stock markets have been recovering since mid 2009. The previous figures also indicate that the situation is on the way to be normalized after the early

18 Formal tests should be implemented to assess the direction of the causality. 
2009 turbulences, as the spread with respect to the German government bond is shrinking again and the debt forecasts for 2010 seem to indicate a lower debt growth rate for 2010.

Nevertheless, potential threats are still present:

First, some countries, Greece in particular, to a lesser extent Ireland, are still problematic. With respect to Greece, the debt-gdp ratio is far above $100 \%$ and is expected to increase by $10 \%$ in 2010 . Concerning Ireland, debt is much lower (around 65\%) but its growth rate is the highest in the Euro area $(50 \%$ this year and still 25\% for 2010). As a consequence government spread for these two countries is increasing again vis a vis of all other Euro area members. The threat lies in the potential default of one of these countries. In such a case, it would be likely ${ }^{19}$ to observe a spill-over of the crisis to all Euro area countries.

Second, governments have provided guarantees to the financial sectors. It helped the markets to regain confidence and to save the banking sector from a global collapse. Nevertheless, as some guarantees remain effective (via private-public partnerships or simply via nationalization as in the UK) they constitute a potential threat. In the case of a country default, banks holding government bonds, may face huge losses which have to be covered by governments. Investor confidence in Euro governments solvency would diminish causing an inevitable contagious transmission of the sovereign debt crisis.

Third, as stressed by Sgherri and Zoli (2009), a huge part of the dynamics of Euro area sovereign spreads is driven by common shocks. It thus means that a crisis will likely be systemic rather than country-specific. Moreover, even if spreads are converging again between Euro area countries, they could disconnect from the U.S. or Japanese government bonds interest rates. In such a case, the Euro would be under pressure, depreciating vis a vis of the USS and the Japanese Yen. The sovereign debt crisis would mute then into a currency crisis. Even if the Euro has recently lost value with respect to the US\$, the interest rate spread between German and U.S. government bonds are stable around $0.2 \%$ since mid October. Moreover, from a historical perspective the value of the Euro is still fairly high compared to the US\$. The likelihood of a currency crisis remains nevertheless a potential threat.

Fourth, all the debates around the probable default of a Euro area country could create the conditions for some speculators to generate a self-fulfilling currency or debt crisis (see Obstfeld 1996 for a theoretical model of self-fulfilling currency crisis). The mechanism behind such an event is simple: as the markets are uncertain about the probability of default of a country, any dev-

19 The contagion phenomenon will be amplified by the high financial and trade interdependence between these countries, as well as by a likely collapse in investors' sentiments in Europe. 
astating news ${ }^{20}$ may provoke a massive sell of domestic government bonds, leading to the impossibility for the government of refinancing and thus to a sovereign debt crisis.

Finally, the Euro area may face serious institutional problems in the case of the default of one of his members. From a legal point of view, the Maastricht treaty contains a no-bail out clause that restricts the ways to provide support to a member country facing default. A legal obligation to provide support is explicitly ruled out. Such an article was included to avoid moral hazard: if systematic help is provided to deficient governments, they will one day or another take advantage of the situation. Nevertheless, as the risk of contagion of a sovereign debt crisis would be important and as it is neither conceivable nor legally possible to exclude a member country from the Euro area, de Grauwe (2009) invokes Art. 100 of the Maastricht treaty, to allow EU governments to freely bail-out a country if needed. Such an intervention could nevertheless not be implemented via the ECB, which contrary to the U.S. Federal reserve system, is not allowed to intervene and finance the deficit encountered by a member country. ECB's possibilities of action are limited to acceptance of bonds as collateral for new loans. So to face liquidity problems and to avoid the rescue by a non-European lender as the IMF, some voices already call for the creation of a European Monetary Fund. Anyway, even if the threat of a sovereign debt crisis disappears, European authorities cannot ignore anymore the possibility of such an event in the future and thus they will have to reassess the legal framework for a common intervention in the light of the crises experiences.

\section{CONCLUSION}

This paper's objective is to shed some light on and to contribute to, the understanding of the causes of a possible mutation of the Sub-Prime crisis into that of a sovereign debt crisis. After presenting the different criteria used to define and measure the debt vulnerability, the balance sheet approach (BSA) is presented in order to illustrate the connections between the different types of crises and the mechanisms propagating a crisis and possibly igniting the next one. In the empirical part, we report the results of a graphical analysis to check the pertinence of the fear for a future sovereign debt crisis in Europe. The analysis leaves us with the feeling that at the end 2009 the probability of observing a Euro area country defaulting is less important than six month earlier. Nevertheless, the serious threats, concerning in particular Greece and Ireland, do not permit to exclude the future occurrence of a contagious or self-fulfilling, sovereign debt or currency crises in the Euro area.

20 For example, a simple interview of George Sorros initiated the speculative attack against the British Pound in 1992. 
Wether or not such a crisis occurs in the coming months, these debates should tend to create a revival of studies on the relation between banking and sovereign debt crises. The story is no more forgotten and it is certain that during the next financial turmoils, particular attention will be paid to the public accounts. The fear of a potential sovereign debt crisis in Euro area, will also force European authorities to update the legal framework to address such events, considering that they are, after all, not so rare.

We can hope that this lesson will strengthen Euro area countries when facing future crises.

Open Access This article is distributed under the terms of the Creative Commons Attribution Noncommercial License which permits any noncommercial use, distribution, and reproduction in any medium, provided the original author(s) and source are credited.

\section{REFERENCES}

Bordo, M.D., B. Eichengreen, D. Klingebiel, and M.S. Martinez-Peria (2001), 'Financial crises: lessons from the last 120 years'. Econ. Policy.

Borensztein, E. and U. Panizza (2009), 'The costs of sovereign default'. IMF Staff Papers, 56(4), pp. 683-741.

Cantor, R. and F. Packer (1995), Sovereign credit ratings. Current Issues in Economics and Finance, Federal Reserve Bank of New York.

Corsetti, G. and B. Mackowiak (2006), 'Fiscal imbalances and the dynamics of currency crises'. Eur. Econ. Rev., 50(5), pp. 1317-1338.

Dell'Ariccia, G., E. Detragiache, and R. Rajan (2008), 'The real effect of banking crises'. J. Finan. Intermed., 17(1), pp. 89-112.

de Grauwe, P. (2009), Greece: the start of a systemic crisis of the Eurozone? vox http: / / www . voxeu. org/index.php?q=node/ 4384 .

Flood, R.P. and P.M. Garber (1984), 'Collapsing exchange rate regimes: some linear examples'. $J$. Int. Econ., 17, pp. 1-13.

Glick, R. and M. Hutchison (2000), Banking and currency crises: how common are the twins? Working Paper No. 01/2000, the Hong Kong Institute for Monetary Research.

Hutchison, M.M. and I. Noy (2006), 'Sudden stops and the Mexican wave: currency crises, capital flow reversals and output loss in emerging markets'. J. Dev. Econ., 79(1), pp. 225-248.

Manasse P., A. Schimmelpfennig, and N. Roubini (2003), Predicting sovereign debt crises. IMF Working Papers 03/221, International Monetary Fund.

Obstfeld, M. (1996), 'Models of currency crises with self-fulfilling features'. Eur. Econ. Rev., 140, pp. 1037-1048.

Pescatori, A. and A.N.R. Sy (2007), 'Are debt crises adequately defined?' IMF Staff Papers, 54(2), pp. 306-337.

Reinhart, C. and K. Rogoff (2009), This time is different: eight centuries of financial folly. Princeton University Press Princeton. 
Reinhart, C.M. and K.S. Rogoff (2008a), The forgotten history of domestic debt. NBER Working Papers 13946, National Bureau of Economic Research.

Reinhart, C.M. and K.S. Rogoff (2008b), Banking crises: an equal opportunity menace. NBER Working Papers 14587, National Bureau of Economic Research.

Reinhart, C.M., K.S. Rogoff, and M.A. Savastano (2003), Addicted to dollars. NBER Working Papers 10015, National Bureau of Economic Research.

Rosenberg, C., I. Halikias, B. House, C. Keller, J.A. Pitt, and B. Setser (2005), Debt-related vulnerabilities and financial crises an application of the balance sheet approach to emerging market countries. IMF Occasional Paper 240.

Sgherri, S. and E. Zoli (2009), Euro area sovereign risk during the crisis. IMF Working Papers 09/222, International Monetary Fund.

Slavila, A. (2008), Sovereign bond rating versus interest rate spreads as measures of sovereign default risk. Master thesis, Maastricht University School of Business and Economics.

Sy, A.N.R. (2004), 'Rating the rating agencies: anticipating currency crises or debt crises?' J. Bank. Finance, 28(11), pp. 845-2867. 